Research Article

\title{
The Influence of Ground Fly Ash on Cement Hydration and Mechanical Property of Mortar
}

\author{
Jingjing Feng $\mathbb{D},{ }^{1}$ Jianwei Sun, ${ }^{2,3}$ and Peiyu $\operatorname{Yan}^{3}$ \\ ${ }^{1}$ College of Hydraulic and Civil Engineering, Shandong Agricultural University, Tai'an, Shandong 271018, China \\ ${ }^{2}$ School of Mechanics and Civil Engineering, China University of Mining and Technology, Beijing 100083, China \\ ${ }^{3}$ Department of Civil Engineering, Tsinghua University, Beijing 100084, China
}

Correspondence should be addressed to Jingjing Feng; fengjingjing@sdau.edu.cn

Received 30 September 2017; Revised 3 February 2018; Accepted 19 February 2018; Published 2 May 2018

Academic Editor: Evangelos J. Sapountzakis

Copyright ( $\odot 2018$ Jinging Feng et al. This is an open access article distributed under the Creative Commons Attribution License, which permits unrestricted use, distribution, and reproduction in any medium, provided the original work is properly cited.

In this study, the ground fly ash is made of ordinary grade I fly ash by grinding. Compared with grade I fly ash, the influence of ground fly ash on cement hydration and mechanical property of mortar was investigated. The results show that ground fly ash can improve the hydration of cement at all the ages compared with grade I fly ash, and not only does its pozzolanic reaction start earlier, but the reaction degree is higher and the speed is quicker. Before 3 days, the contribution of ground fly ash to the strength is mainly due to physical filling and microaggregate effect. After that, the contribution of pozzolanic effect to the strength becomes obvious and can significantly increase the compressive strength after 60 days and the flexural strength after 28 days. The ground fly ash is better than grade I fly ash to optimize the pore structure of hardened pastes. It can significantly reduce the number of harmful pores $(>20 \mathrm{~nm})$ and increase the number of harmless pores $(<20 \mathrm{~nm})$, which refines the pore structure and makes the structure denser.

\section{Introduction}

Fly ash is a by-product from the residue of coal combustion, and it is a kind of pozzolana. Fly ash tends to be spherical and micrometers to millimeters particles and has a relatively high reactivity depending on the chemical formation of its individual particle [1]. These made the demand of fly ash grow steadily over the past 30 years $[2,3]$, especially in concrete and construction industries $[3,4]$. Therefore, fly ash has become the most widely used mineral admixtures in all kinds of concrete $[5,6]$. The main chemical components of fly ash are $\mathrm{Al}_{2} \mathrm{O}_{3}, \mathrm{SiO}_{2}$, and $\mathrm{Fe}_{2} \mathrm{O}_{3}$ [7]. And fly ash consists of a major amorphous phase and a small amount of crystalline phases $[8,9]$. At early ages of hydration, fly ash particles often act as microaggregates to fill the pores of binders and nuclei for the hydration products [10]. While at later ages, the chemical effect of fly ash works. Fly ash can react with $\mathrm{Ca}(\mathrm{OH})_{2}$, which is a product of cement hydration, to form $\mathrm{C}-\mathrm{S}-\mathrm{H}$ gel $[11,12]$. This is the so-called pozzolanic reaction. The pozzolanic reaction of fly ash is much slower than the hydration of cement [13].
The utilization of fly ash not only saves energy but also improves the properties of concrete. With the fly ash addition, the heat of hydration of high-volume concrete is reduced [14-16]. Liu et al. [17] proved that fly ash could improve the fluidity of concrete. Fly ash also can decrease the drying shrinkage of concrete to some degree [18-21]. Furthermore, an appropriate addition of fly ash could enhance the resistance of concrete to sulfate attack and chloride penetration [22-24], thus reducing the risk of steel corrosion [25]. Other properties such as strength [6], acid resistance [26], wear resistance [27], and leaching properties [28] could be improved by replacing part of cement with fly ash.

The specific surface area of the fly ash used in current practical engineering is between 300 and $400 \mathrm{~m}^{2} / \mathrm{kg}$. Fly ash with a specific surface area of 600 to $700 \mathrm{~m}^{2} / \mathrm{kg}$ can be obtained from grinding. A large part of the glass phase can be ground up to pieces. And the particle size of fly ash is mainly distributed below $10 \mu \mathrm{m}$ by grinding. The activity of fly ash depends mainly on the structures and properties of the amorphous composition. And the filling effect of fly ash 
TABle 1: Chemical compositions of cement and fly ash.

\begin{tabular}{lccccccccc}
\hline Composition & $\mathrm{SiO}_{2}$ & $\mathrm{Al}_{2} \mathrm{O}_{3}$ & $\mathrm{Fe}_{2} \mathrm{O}_{3}$ & $\mathrm{CaO}$ & $\mathrm{MgO}$ & $\mathrm{SO}_{3}$ & $\mathrm{Na}_{2} \mathrm{O}$ & $\mathrm{f}-\mathrm{CaO}^{-}$ & $\mathrm{Cl}^{-}$ \\
\hline Cement & 21.56 & 4.44 & 2.78 & 62.83 & 2.32 & 3.14 & 0.6 & 0.79 & 0.01 \\
Fly ash & 57.60 & 21.90 & 2.70 & 3.87 & 1.68 & 0.41 & 1.05 & - & - \\
\hline
\end{tabular}

depends mainly on the particle size. Therefore, theoretically it is practicable to make fly ash play a greater role in concrete by grinding.

In this research, pure cement and ordinary fly ash were used as a reference. With a variety of experimental test methods, the effects of ground fly ash and grade I fly ash on cement hydration, pore structures of hardened pastes, and strength of mortar were comparatively studied. More importantly, the mechanism of grinding fly ash in hydration and hardening of cement-based composite cementitious materials was discussed.

\section{Materials and Methods}

2.1. Raw Materials. An ordinary Portland cement which is used for testing admixtures was applied in our research, and the specific surface area of the cement is $346 \mathrm{~m}^{2} / \mathrm{kg}$. Grade I fly ash used was produced by a thermal power plant in China, the specific surface area of the fly ash is $384 \mathrm{~m}^{2} / \mathrm{kg}$, and water demand is $88 \%$. The chemical composition of cement and grade I fly ash is shown in Table 1. Standard sand was used as the aggregate for mortar specimens. Polycarboxylate superplasticizer with water reduction rate $19.1 \%$ was used to adjust the flowability and workability of fresh mortars and pastes.

The ground fly ash was made of grade I fly ash using the ball milling method in the laboratory. The rotating speed is $250 \mathrm{rad} / \mathrm{min}$, ball to binder ratio is $4: 1$, and the milling time is 5 hours. The specific surface area of the prepared ground fly ash is $651 \mathrm{~m}^{2} / \mathrm{kg}$, and its water demand is $97 \%$. The microstructures of ordinary and ground fly ash are shown in Figures 1 and 2, respectively. And the particle size distribution of the three raw materials is shown in Figure 3.

\subsection{Mix Methods}

2.2.1. Mortar Specimens. Three groups of mortar specimens were prepared. Pure cement mortar was the reference group, and the other two groups were mortar with $25 \%$ grade I fly ash addition and mortar with $25 \%$ ground fly ash addition. The three groups of mortars were marked as Cement, FA$25 \%$, and GFA-25\%. Their sand to binder ratios and water to binder ratios were $3: 1$ and 0.4 , respectively. The superplasticizer was added to the mortars to achieve a jumping table flow of $200 \pm 5 \mathrm{~mm}$. The specimens were cured in standard curing boxes for 28 days and then cured in water and ambient temperature to the testing age.

2.2.2. Hardened Paste Specimens. The hardened paste specimens were casted and cured in the same conditions as

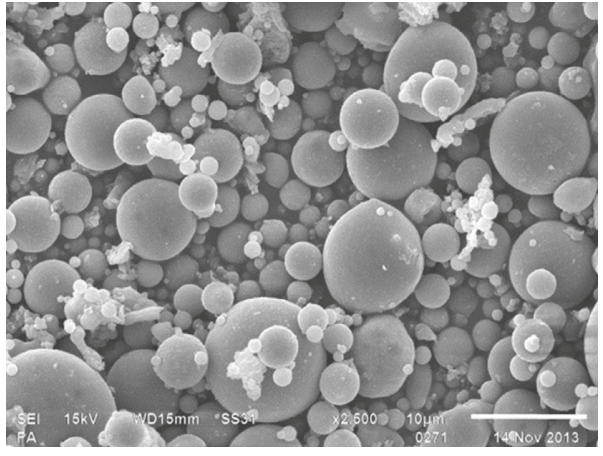

FIGURE 1: Micromorphology of grade I fly ash.

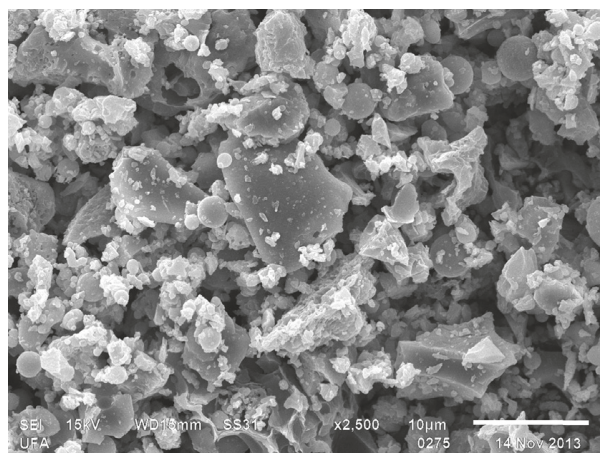

Figure 2: Micromorphology of ground fly ash.

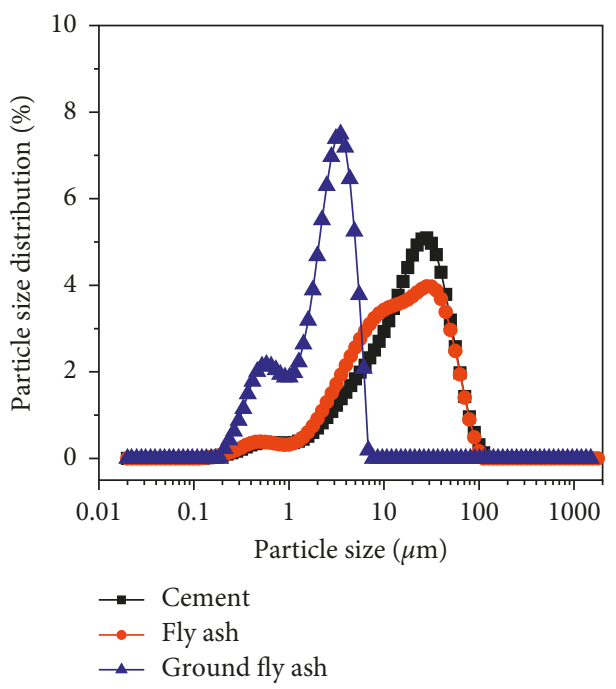

FIGURE 3: Particle size distribution of raw materials.

mortar specimens. The specimens were immersed in acetone to discontinue the hydration of pastes at the testing age and used for microstructure analysis. 

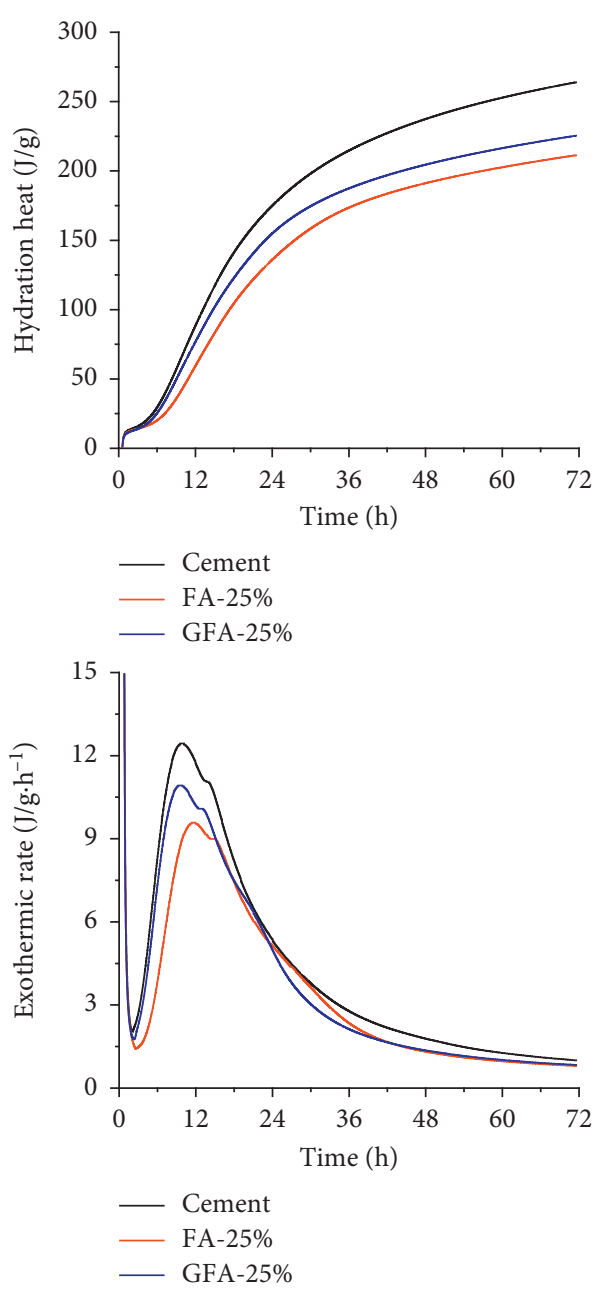

FIgURE 4: Hydration heat curves of composite cementitious materials.

\section{Results and Discussion}

3.1. Heat of Hydration. The hydration heat of composite cementitious materials was tested by using ToniTechnik7338 Isothermal Differential Calorimeter. The cumulative hydration heat $\mathrm{Q}$ and exothermic rate $\mathrm{dQ} / \mathrm{dt}$ were measured within the initial 72 hours at $25^{\circ} \mathrm{C}$. The water to binder ratios kept 0.4 and the total mass of binders was $6 \mathrm{~g}$ in each experiment. The cumulative hydration heat and exothermic rate of all the samples are exhibited in Figure 4.

Figure 4 shows that the additions of grade I fly ash and ground fly ash both lowered the hydration heat compared to that of pure cement, because replacing part of cement with fly ash resulted in the reducing content of cement in binders. In comparison with pure cement, the second exothermic peak of binder with grade I fly ash addition appeared later, while with ground fly ash addition, the second exothermic peak appeared earlier. In addition, the total hydration heat and exothermic rate of Sample GFA-25\% were both higher than Sample FA-25\%.

In the process of hydration, the precipitation of $\mathrm{C}-\mathrm{S}-\mathrm{H}$ and $\mathrm{Ca}(\mathrm{OH})_{2}$ required $\mathrm{Ca}^{2+}$ concentration in the solution reaches the saturation. When replacing part of cement with grade I fly ash, some of $\mathrm{Ca}^{2+}$ was adsorbed on the surfaces of fly ash particles and the decrease of the cement content led to the decrease of $\mathrm{Ca}^{2+}$ concentration in the liquid phase, thus delaying the time of $\mathrm{Ca}^{2+}$ to reach saturation. Therefore, adding grade I fly ash has an effect of delaying the early-age hydration and further delay the time of the appearance of the second exothermic peak. However, the particle size of ground fly ash is significantly smaller than that of grade I fly ash. In the early-age hydration of Sample GFA-25\%, the fly ash particles act as nucleation of the cement's hydration products, which to some extent can promote the hydration and thus slightly advance the second exothermic peak.

3.2. Thermal Analysis. The content of $\mathrm{Ca}(\mathrm{OH})_{2}$ in hardened pastes was measured by thermogravimetry (TG). In order to prevent carbonization of hardened pastes during the heating process, $\mathrm{N}_{2}$ was used as the protective atmosphere. The heating rate was $10^{\circ} \mathrm{C} / \mathrm{min}$ and the maximum temperature was $900^{\circ} \mathrm{C}$ in TG tests. The TG-DTG results of the three kinds of pastes at the age of 3, 28, 90, and 360 days are presented in Figure 5, and the corresponding $\mathrm{Ca}(\mathrm{OH})_{2}$ contents are shown in Table 2. $\Delta_{1}$ and $\Delta_{2}$ in Table 2, respectively, represented the difference values in $\mathrm{Ca}(\mathrm{OH})_{2}$ contents of FA- $25 \%$ and GFA- $25 \%$ compared to $75 \% \mathrm{Ca}(\mathrm{OH})_{2}$ content of Cement.

The continuous hydration of cement leads to the constant increase of $\mathrm{Ca}(\mathrm{OH})_{2}$ content, but the pozzolanic reaction of fly ash will consume some $\mathrm{Ca}(\mathrm{OH})_{2}$. A large number of studies $[29,30]$ have shown that the reaction degree of fly ash at the age of 3 days is generally less than $5 \%$ and at the age of 7 days less than $10 \%$. It can be referred from Table 2 that $\mathrm{Ca}(\mathrm{OH})_{2}$ content of FA-25\% and GFA-25\% increased first and then decreased with the increase of ages, which was due to the relative values between forming rate and consuming rate of $\mathrm{Ca}(\mathrm{OH})_{2}$. However, $\mathrm{Ca}(\mathrm{OH})_{2}$ content of GFA-25\% was less than that of FA-25\% at all ages. Furthermore, $\mathrm{Ca}(\mathrm{OH})_{2}$ content of GFA-25\% reached its maximum at the age of 90 days while $\mathrm{Ca}(\mathrm{OH})_{2}$ content of FA-25\% reached its maximum at the age of 28 days. This indicates that the pozzolanic activity of ground fly ash is higher than that of grade I fly ash and that ground fly ash has more significant effect on promoting the hydration of cement.

It is known from hydration heat analysis that grade I fly ash retards the early-age hydration of cement, but $\Delta_{1}$ kept positive from 3 days to 28 days and increased with ages, indicating that fly ash promotes the hydration of cement. The higher slope of hydration heat curve of FA-25\% after 24 hours compared to that of Cement also proves this point. The main reason is that addition of grade I fly ash increased the effective water to cement ratio so that the retarding effect of grade I fly ash on hydration appeared mainly in the initial 24 hours. $\Delta_{1}$ reached maximum at 28 days, then generally changed to negative, and grew negatively, indicating that the pozzolanic reaction of grade I fly ash presented very low degree within initial 28 days, but the reaction degree was obviously promoted after 28 days and the hydration rate 

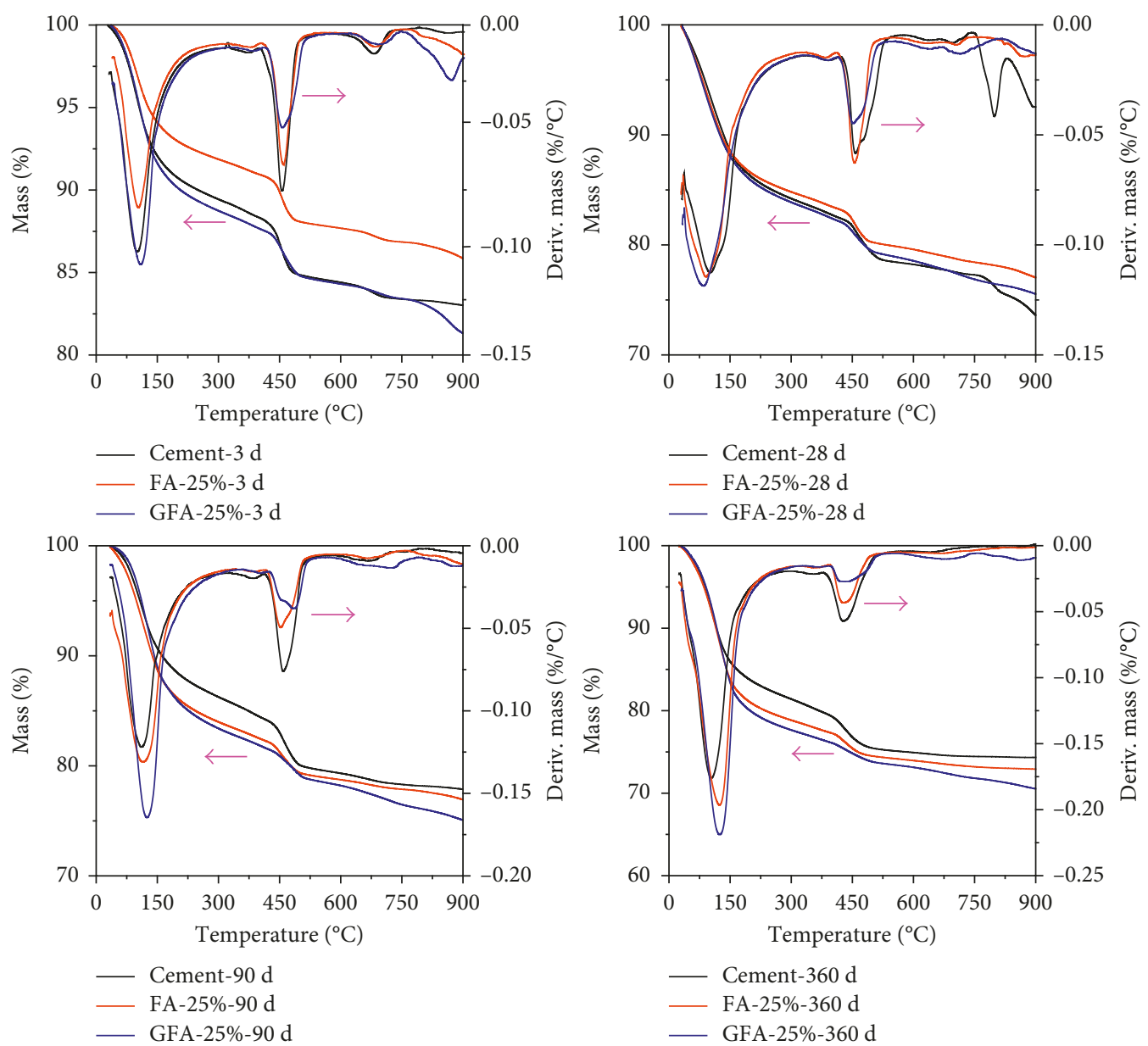

Figure 5: TG-DTG curves of composite cementitious materials.

exceeded that of Cement, resulting in more $\mathrm{Ca}(\mathrm{OH})_{2}$ consumption than its formation and negative $\Delta_{1}$; the value of $\Delta_{1}$ expressed little difference at 90 days and 360 days, indicating that the pozzolanic reaction of grade I fly ash was relatively fast from 28 days to 90 days and then became slow.

$\Delta_{2}$ of GFA-25\% was positive at 3 days, meaning that ground fly ash always promoted the hydration of cement. After 3 days, $\Delta_{2}$ significantly grew negatively with the increase of ages, indicating that after 3 days the pozzolanic activity of ground fly ash began to increase greatly and the hydration rate of GFA-25\% was higher than that of Cement, even at the ages of up to 360 days. It can be seen from the data in Table 2 that the pozzolanic reaction degree of ground fly ash is slightly higher than that of grade I fly ash at initial 3 days, while after 3 days, the pozzolanic activity of ground fly ash began to increase significantly and is greatly higher than that of grade I fly ash. With the increase of ages, the gap of pozzolanic activity between ground fly ash and grade I fly ash became significant.

3.3. Compressive Strength and Flexural Strength. The changes of compressive strength and flexural strength of three kinds of mortars with ages are shown in Figures 6 and 7, respectively.
TABle 2: The content of $\mathrm{Ca}(\mathrm{OH})_{2}$ in the hardened cement paste at different ages (\%).

\begin{tabular}{lccccc}
\hline Age & Cement & FA-25\% & GFA-25\% & $\Delta_{1}$ & $\Delta_{2}$ \\
\hline $3 \mathrm{~d}$ & 16.60 & 13.30 & 13.14 & 0.86 & 0.69 \\
$28 \mathrm{~d}$ & 18.36 & 15.73 & 13.03 & 1.96 & -0.74 \\
$90 \mathrm{~d}$ & 21.20 & 15.52 & 14.76 & -0.38 & -1.14 \\
$360 \mathrm{~d}$ & 21.48 & 15.48 & 13.36 & -0.63 & -2.75 \\
\hline
\end{tabular}

Figure 6 shows that, in the initial 28 days, the compressive strength of Cement was the biggest and grew fast, but grew slowly after 28 days, whereas the compressive strengths of FA-25\% and GFA-25\% basically maintained a line growing trend until 360 days and the compressive strength of GFA-25\% was higher and grew faster than that of FA-25\%. At the age of 360 days, the compressive strength of GFA-25\% was 1.25 times that of Cement while the compressive strength of FA-25\% was still less than that of Cement, indicating that the contribution of ground fly ash to pozzolanic activity was higher than that of grade I fly ash, and the pozzolanic activity of ground fly ash worked earlier than that of grade I fly ash. After 3 days, the pozzolanic activity of ground fly ash began to work and continuously contributed to compressive strength. These results are consistent with TG-DTG results. 


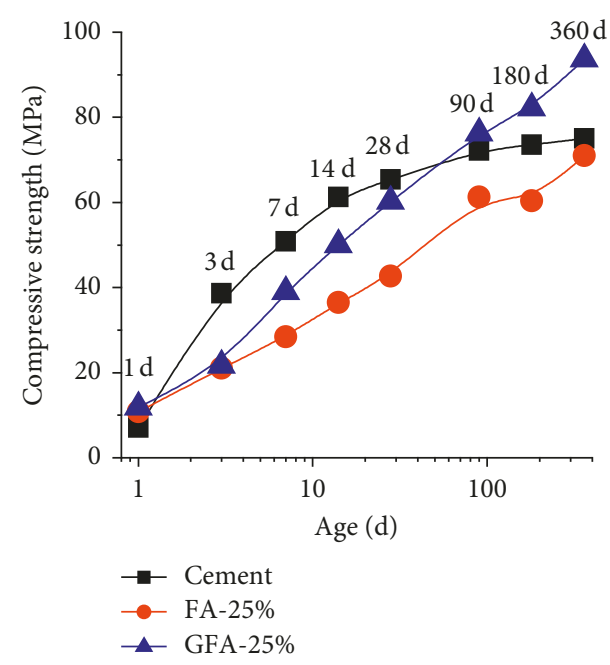

Figure 6: The compressive strength versus ages.

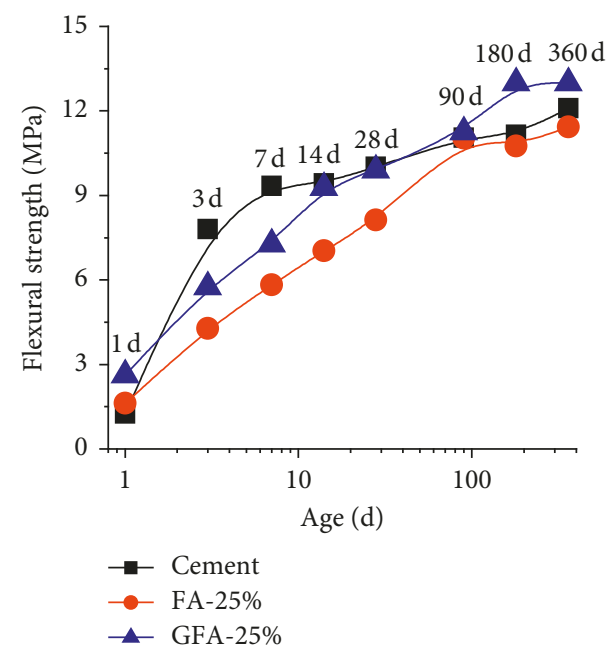

FIgURE 7: The flexural strength versus ages.

Figure 7 shows that the growing trend of flexural strength was similar to that of compressive strength. The difference was that, at 1 day, the flexural strength of GFA$25 \%$ was obviously higher than that of the other two mortars. Because the hydration degree at 1 day was very low so that the filling effect and microaggregate effect of ground fly ash worked. At the age of 14 days, the flexural strength of GFA$25 \%$ was almost the same as that of Cement. For comparative study, mortar with $50 \%$ ground fly ash was casted with the same w/b. Its flexural strength was higher than that of the other three mortars at 28 days and 1.06 times that of Cement, but its compressive strength did not exceed that of Cement until 180 days. Therefore, adding ground fly ash is more beneficial to improve flexural strength than compressive strength of mortar. The more the replacement ratio is, the higher the later-age (after 28 days) flexural strength will be. This may be mainly related to the fineness of ground fly ash and the morphology of the particles after mechanical grinding. The fine fly ash particles can fill the pores between

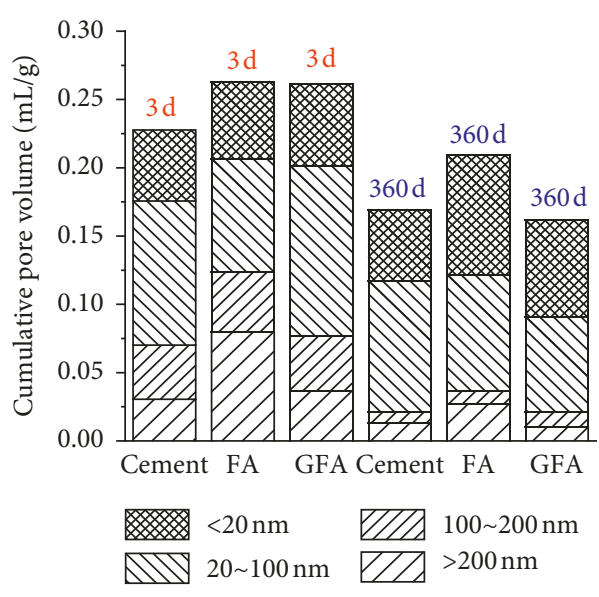

FIGURE 8: Cumulative pore volume histogram.

the hydration products, and it makes the microstructure denser, thus improving the flexural strength of mortar.

3.4. Pore Structures. Autopore II 9220 mercury intrusion porosimeter was applied to determine the porosity of hardened pastes. The maximum pressure of the tests was $400 \mathrm{MPa}$, and pores between $3 \times 10^{5} \mathrm{~nm}$ and $3.14 \times 10^{5} \mathrm{~nm}$ could be examined. The pores were classified as follows: harmless pores $(<20 \mathrm{~nm})$, little harmful pores $(20-100 \mathrm{~nm})$, harmful pores $(100-200 \mathrm{~nm})$, and much harmful pores $(>200 \mathrm{~nm})$. The pore structures of different kinds of hardened pastes are shown in Figure 8 according to this classification method.

It can be learned from Figure 8 that, at the age of 3 days, the cumulative pore volume and much harmful pores of Cement were the least, so that its compressive strength and flexural strength were the highest (as shown in Figures 6 and 7); the cumulative pore volume of FA-25\% and GFA-25\% was almost the same, but the number of much harmful pores in FA-25\% was twice that in GFA-25\%, leading to the lowest compressive strength and flexural strength of FA-25\%.

With the increase of ages, the hydration degree of cement continuously increased and the pozzolanic activity of fly ash gradually appeared. The newly formed hydration products were constantly filling the pores of the hardened pores, so the total pore volume of the three mixes significantly decreased. Nevertheless, at the age of 360 days, the number of harmless pores in FA-25\% and GFA-25\% had a significant increase, indicating that the $\mathrm{C}-\mathrm{S}-\mathrm{H}$ and/or $\mathrm{C}-\mathrm{A}-\mathrm{H}$ gel formed from the pozzolanic reaction between fly ash and $\mathrm{Ca}(\mathrm{OH})_{2}$ had a good refining effect on pore structures. Furthermore, the number of harmless pores in GFA-25\% was the least, indicating that the refining effect of ground fly ash on pore structures was the greatest.

\section{Conclusions}

(1) At early ages, ground fly ash can promote the hydration of cement and making the second exothermic peak appear slightly earlier. The pozzolanic activity of ground fly ash after $3 \mathrm{~d}$ is obviously 
increased and the hydration rate is greater than that of cement. Compared with grade I fly ash, not only the beginning of pozzolanic reaction of ground fly ash is earlier, but also the degree of reaction and the overall reaction rate of ground fly ash is higher.

(2) The addition of ground fly ash could avoid the decrease of strength which occurs in the addition of ordinary fly ash, and it can improve the strength at middle and late age (after 60 days). The contribution of ground fly ash to the strength before 3 days is mainly due to filling effect and microaggregate effect. Ground fly ash has a significant contribution to strength after 3 days due to the significant increase in pozzolanic activity. Compared to compressive strength, the addition of ground fly ash is more beneficial to improve the flexural strength.

(3) The positive effect of ground fly ash on pore structures is more significant than that of grade I fly ash, which makes the number of harmful pores $(>20 \mathrm{~nm})$ decrease significantly and the number of harmless holes $(<20 \mathrm{~nm})$ increase significantly, and thus the microstructure is denser.

\section{Conflicts of Interest}

The authors declare that they have no conflicts of interest.

\section{Acknowledgments}

The authors would like to acknowledge the support from National Natural Science Foundation of China (no. 51678344).

\section{References}

[1] M. Aboustait, T. Kim, M. T. Ley, and J. M. Davis, "Physical and chemical characteristics of fly ash using automated scanning electron microscopy," Construction and Building Materials, vol. 106, pp. 1-10, 2016.

[2] R. S. Blissett and N. A. Rowson, "A review of the multicomponent utilisation of coal fly ash," Fuel, vol. 97, no. 7, pp. 1-23, 2012.

[3] M. Ahmaruzzaman, "A review on the utilization of fly ash," Progress in Energy and Combustion Science, vol. 36, no. 3, pp. 327-363, 2010.

[4] H. W. Nugteren, "Coal fly ash: from waste to industrial product," Particle and Particle Systems Characterization, vol. 24, no. 1, pp. 49-55, 2007.

[5] Z. Huang, T. Zhang, and Z. Wen, "Proportioning and characterization of Portland cement-based ultra-lightweight foam concretes," Construction and Building Materials, vol. 79, pp. 390-396, 2015.

[6] W. Wongkeo, P. Thongsanitgarn, A. Ngamjarurojana, and A. Chaipanich, "Compressive strength and chloride resistance of self-compacting concrete containing high level fly ash and silica fume," Materials and Design, vol. 64, no. 9, pp. 261-269, 2014.

[7] A. Noushini, K. Vessalas, G. Arabian, and B. Samali, "Drying shrinkage behaviour of fibre reinforced concrete incorporating polyvinyl alcohol fibres and fly ash," Advances in Civil Engineering, vol. 2014, Article ID 836173, 10 pages, 2014.
[8] A. Fernández-Jiménez and A. Palomo, "Composition and microstructure of alkali activated fly ash binder: effect of the activator," Cement and Concrete Research, vol. 35, no. 10, pp. 1984-1992, 2005.

[9] C. R. Ward and D. French, "Determination of glass content and estimation of glass composition in fly ash using quantitative X-ray diffractometry," Fuel, vol. 85, no. 16, pp. 2268-2277, 2006.

[10] A. Wang, C. Zhang, and W. Sun, "Fly ash effects: iii. The microaggregate effect of fly ash," Cement and Concrete Research, vol. 34, no. 11, pp. 2061-2066, 2004.

[11] W. Ma and P. W. Brown, "Hydrothermal reactions of fly ash with $\mathrm{Ca}(\mathrm{OH})_{2}$ and $\mathrm{CaSO}_{4} \cdot 2 \mathrm{H}_{2} \mathrm{O}$," Cement and Concrete Research, vol. 27, no. 8, pp. 1237-1248, 1997.

[12] W. Qiang, S. Mengxiao, and W. Dengquan, "Contributions of fly ash and ground granulated blast furnace slag to the early hydration heat of composite binder at different curing temperatures," Advances in Cement Research, vol. 28, no. 5, pp. 320-327, 2016.

[13] S. Hanehara, F. Tomosawa, M. Kobayakawa, and K. R. Hwang, "Effects of water/powder ratio, mixing ratio of fly ash, and curing temperature on pozzolanic reaction of fly ash in cement paste," Cement and Concrete Research, vol. 31, no. 1, pp. 31-39, 2001.

[14] Y. Zhang, W. Sun, and S. Liu, "Study on the hydration heat of binder paste in high-performance concrete," Cement and Concrete Research, vol. 32, no. 9, pp. 1483-1488, 2002.

[15] K. Amnadnua, W. Tangchirapat, and C. Jaturapitakkul, "Strength, water permeability, and heat evolution of high strength concrete made from the mixture of calcium carbide residue and fly ash," Materials and Design, vol. 51, no. 5, pp. 894-901, 2013.

[16] H. Fanghui, L. Renguang, W. Dongming, and Y. Peiyu, "Characteristics of the hydration heat evolution of composite binder at different hydrating temperature," Thermochimica Acta, vol. 586, no. 8, pp. 52-57, 2014.

[17] B. Liu, Y. Xie, and J. Li, "Influence of steam curing on the compressive strength of concrete containing supplementary cementing materials," Cement and Concrete Research, vol. 35, no. 5, pp. 994-998, 2005.

[18] L. Mengyuan, W. Qiang, and Y. Jun, "Influence of steam curing method on the performance of concrete containing a large portion of mineral admixtures," Advances in Materials Science and Engineering, vol. 2017, Article ID 9863219, 11 pages, 2017.

[19] P. Chindaprasirt and U. Rattanasak, "Shrinkage behavior of structural foam lightweight concrete containing glycol compounds and fly ash," Materials and Design, vol. 32, no. 2, pp. 723-727, 2011.

[20] S. A. Kristiawan and M. T. M. Aditya, "Effect of high volume fly ash on shrinkage of self-compacting concrete," Procedia Engineering, vol. 125, pp. 705-712, 2015.

[21] Y. Jun, W. Qiang, and Z. Yuqi, "Influence of curing time on the drying shrinkage of concretes with different binders and water-to-binder ratios," Advances in Materials Science and Engineering, vol. 2017, Article ID 2695435, 10 pages, 2017.

[22] P. Dinakar, M. K. Reddy, and M. Sharma, "Behaviour of selfcompacting concrete using Portland pozzolana cement with different levels of fly ash," Materials and Design, vol. 46, no. 4, pp. 609-616, 2013.

[23] S. Mengxiao, W. Qiang, and Z. Zhikai, "Comparison of the properties between high-volume fly ash concrete and high-volume steel slag concrete under temperature matching 
curing condition," Construction and Building Materials, vol. 98, pp. 649-655, 2015.

[24] J. Zuquan, S. Wei, Z. Yunsheng, J. Jinyang, and L. Jianzhong, "Interaction between sulfate and chloride solution attack of concretes with and without fly ash," Cement and Concrete Research, vol. 37, no. 8, pp. 1223-1232, 2007.

[25] W. Chalee, P. Ausapanit, and C. Jaturapitakkul, "Utilization of fly ash concrete in marine environment for long term design life analysis," Materials and Design, vol. 31, no. 3, pp. 12421249, 2010.

[26] A. Mehta and R. Siddique, "Sulfuric acid resistance of fly ash based geopolymer concrete," Construction and Building Materials, vol. 146, pp. 136-143, 2017.

[27] Y. Gao, B. He, Y. Li, J. Tang, and L. Qu, "Effects of nanoparticles on improvement in wear resistance and drying shrinkage of road fly ash concrete," Construction and Building Materials, vol. 151, pp. 228-235, 2017.

[28] A. K. Saha and P. K. Sarker, "Sustainable use of ferronickel slag fine aggregate and fly ash in structural concrete: mechanical properties and leaching study," Journal of Cleaner Production, vol. 162, pp. 438-448, 2017.

[29] L. Lam, Y. L. Wong, and C. S. Poon, "Degree of hydration and gel/space ratio of high-volume fly ash/cement systems," Cement and Concrete Research, vol. 30, no. 5, pp. 747-756, 2000.

[30] Y. M. Zhang, W. Sun, and H. D. Yan, "Hydration of high-volume fly ash cement pastes," Cement and Concrete Composites, vol. 22, no. 6, pp. 445-452, 2000. 


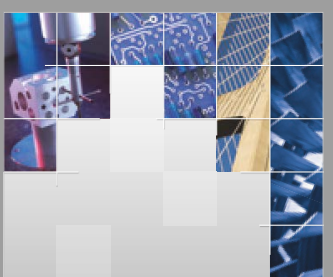

\section{Enfincering}
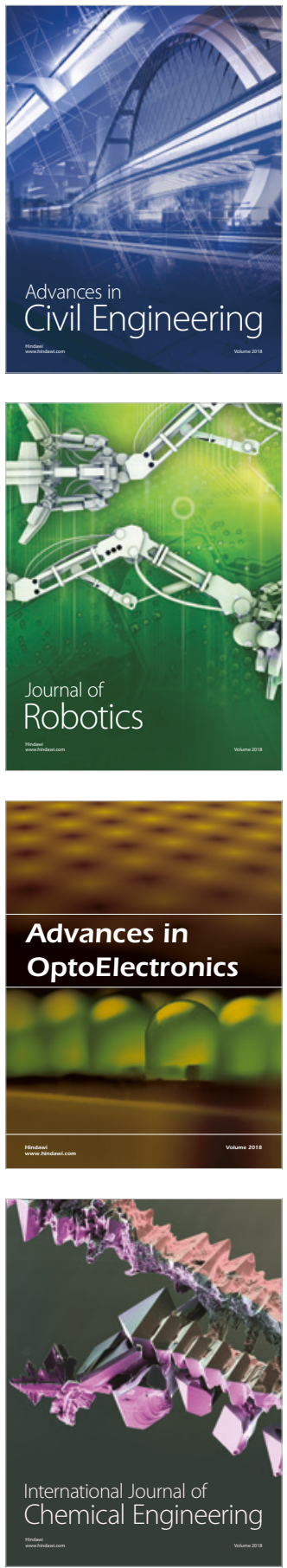

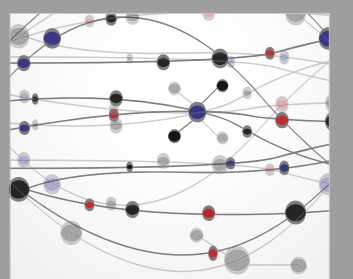

\section{Rotating \\ Machinery}

The Scientific World Journal

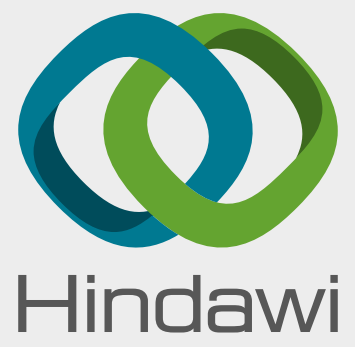

Submit your manuscripts at

www.hindawi.com
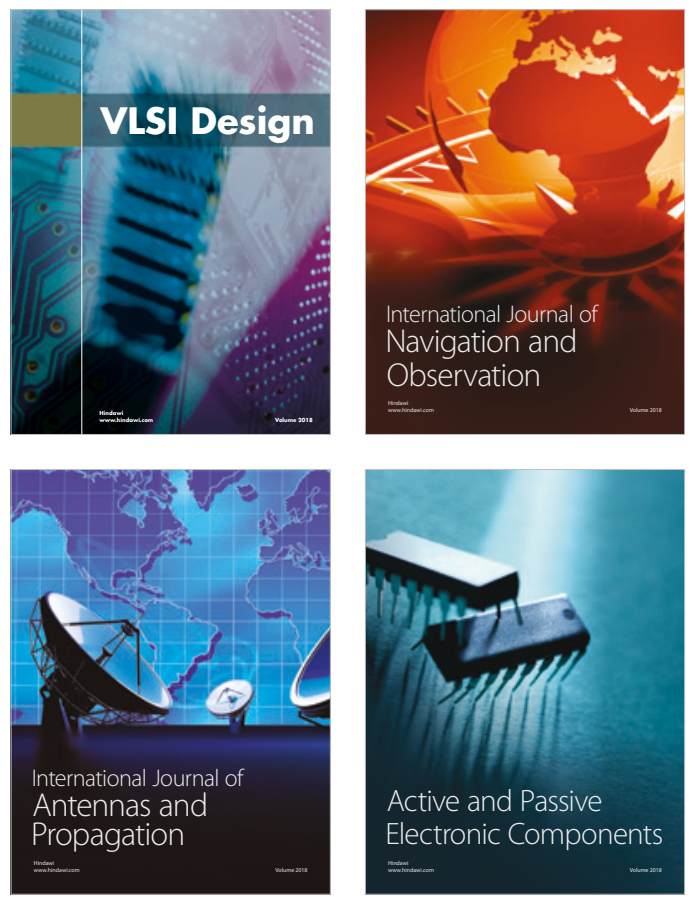
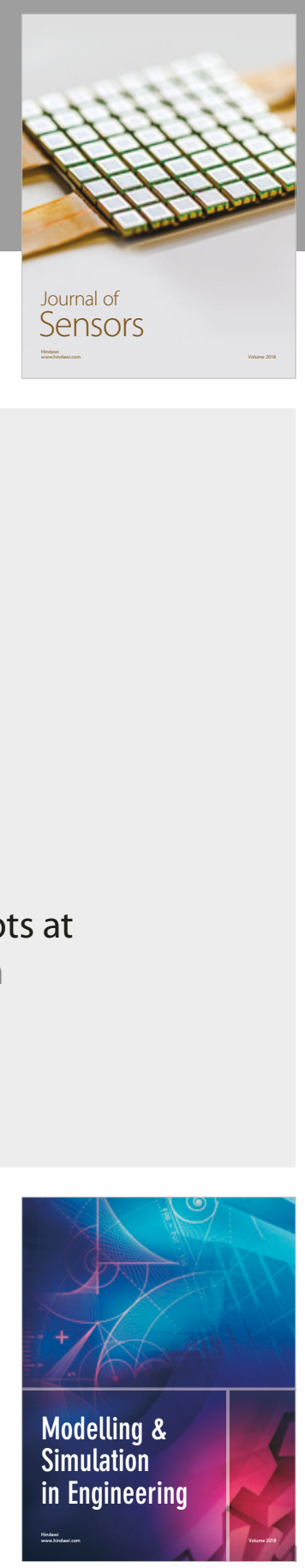

\section{Advances \\ Multimedia}
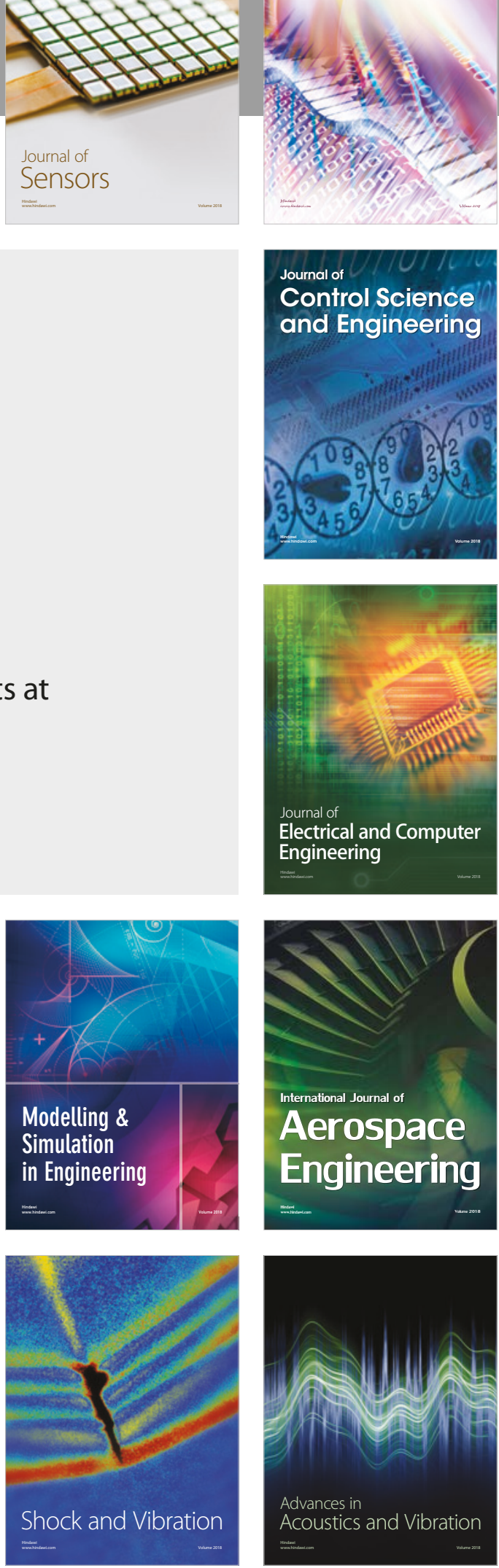